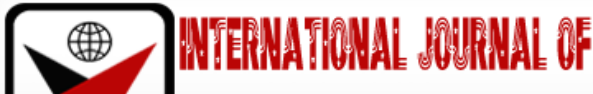

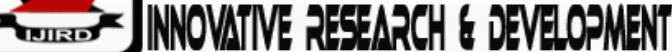

ISSN 2278 - 0211 (Online)

\section{Individual Fundamentals and Financial Performance of Civil Contractors in Kirinyaga County, Kenya}

\author{
EliubComba Muriithi \\ MBA Student, Kenyatta University, Kenya \\ Dr. Mungai John N.
}

Lecturer, Departments of Accounting and Finance, Kenyatta University, Kenya

\begin{abstract}
:
Civil contractors are entrepreneurs involved in the management of construction projects which are considered to be part of small businesses. 2016 annual budget implementation report for Kirinyaga County showed that the monitoring and evaluation of construction process was affected by various characteristics. Hence; the study focused on individual fundamentals of entrepreneurship and financial performance of civil contractors in Kirinyaga County, Kenya which had affected the monitoring and evaluation process. The specific objective was to establish how individual entrepreneurship competencies affect financial performance of civil contactors in the county. The study was affixed in the Kirzner's Theory of Entrepreneurship supported by Innovation Theory. The study used descriptive research design and the target population was the 500 civil contractors who had been awarded tenders by the County Government of Kirinyaga in the 2015/16 Financial Year. Stratified random sampling was used to get the desired number of respondents. The sample frame consisted of 100 main contractors, 18 women contractors, 27 youth contractors and 5 physically challenged contractors totaling to150 respondents. Data was collected using questionnaires which were administered using a drop and pick method and then analyzed using the Statistical Packages for the Social Studies. Data was presented using bar graphs and tables. Findings of the study indicated that individual fundamentals have a significant positive effect on financial performance of civil contactors in Kirinyaga County, Kenya. The study recommended that further study should be done on the effect of other entrepreneurship fundamentals on financial performance of civil contractors.
\end{abstract}

Keywords: Individual entrepreneurship fundamentals, civil contactors

\section{Background of the Study}

Economists perceive entrepreneurship as a key accelerator of economic growth and job openings in societies. This was evident in the past Global Entrepreneurship Summits held in Kenya in 2015 and in the USA in 2016. According to Shane \&Venkataraman, (2000), in the third world countries up-and-coming micro businesses are the key drivers of employment opportunities, revenue growth, and wealth creation. In 2003, Business and Industry Advisory Committee to the Organization for Economic Cooperation and Development (OECD) purported that guidelines to instil entrepreneurial skills are important to employment and economic growth. Entrepreneurs can be encouraged to assume risks of starting new undertakings through government availing incentives to them.

According to the World Economic Forum (2003), six major factors extending from developing human capital through learning and development to the upcoming China-Africa dialogue were recognized be the Global Agenda Council on Africa. Entrepreneurship entails identification of business minded people, business opportunities and procedures used in exploitation and evaluation. According to Ireland, Hitt, \&Sirmon, (2003), in entrepreneurship individuals and groups generate wealth by mobilizing exclusive resources to take advantage of market demands. Entrepreneurship is viewed as the mind-set and procedure used in cultivating financial activity by incorporating risk-taking and innovation with proper administration within an organisation (Commission of the European Communities, 2003).

Initially, entrepreneurship was considered by Schumpeter (1934) as being important to economic growth. He sees entrepreneurship as the imbalance in a firm or economy caused by introduction of new mix of resources occurring within and across organizations. According to Zahra (2009), the degree of entrepreneurship varies within the organization. The final performance of organizations is dependent on how the embrace entrepreneurship. 


\subsection{Entrepreneurship Fundamentals}

Entrepreneurship refers to a special, inherent capability to recognize and act on opportunity by bringing together innovativeness and determination to create a new product or service which can only be evident after time has passed. Entrepreneurship therefore explains a situation where opportunity is found and a set of fundamentals are required in order to create a certain result (Osberg 2007).

According to Schumpeter (1934) and Hisrich\& Peters (2002), the fundamentals that affect entrepreneurship in the established firms are individual based, socio- based, organizational based or environmentally based. Several studies directed to the relationship between commercial entrepreneurship dimensions such as age of companies and the nature of business has been carried out especially in developed countries (Antoncic\& Scarlet, 2008).

\subsection{Individual Fundamentals}

Intrapreneurial behaviour is explained as the process of discovering and using opportunities by employees to help an organization move forward in the business world. These opportunities vary since all employees portray different individual characteristics. Individual behaviour refers to a superior mentality which explains the association between individuals' inventive, practical and risk-taking behaviours (Shane, Locke \& Collins, 2003).

The entrepreneur is attracted to suboptimal equilibrium where he sees a chance to present new goods, services and ways of solving old problems. This drive to bring new changes comes from innate characteristics which when combined serve to encourage, generate and direct action all which is important in innovation (Morris, 2008). In other instances, the motivation comes from frustrations encountered while using products or services that do not meet their requirements. Others jump at the chance to modify things that they posse ensure a better life (Huse, 2005).

Throughout the course of innovation, entrepreneurs show audacity, by shouldering the weight of risk. To be able to do this, the entrepreneurs must own the resilience to propel their creative solutions through to the end. No entrepreneurship undertaking goes on as planned at all times or without drawbacks, but the entrepreneur needs to come up with ways to manoeuvre out of any challenge that comes up (Shane, Locke \& Collins, 2003).

The most crucial aspect of entrepreneurship is innovation. Peter F. Drucker explained it as the aspect that causes performance to change and can be seen in two different perspectives. New or radical innovation is seen when there is a technological breakthrough or a new product is introduced in the market. The other type is the progressive innovations where existing products are worked on to create new ones. Elsewhere, imitations of existing products serve to create new ones especially in developing countries (Boyatzis, 2002).

Competence is a fundamental attribute in a person that is linked by chance to a successful performance in a job. It refers to the people's fundamentals which enable their performance or effectiveness at work. The root of this competency lies in the identification and definition of the fundamentals which define successful managers.

Self-efficacy can be explained as is defined as the progressive capability that one has of transforming innate skills to a desired product or skill. According to Shane et al., (2003), specific tasks are completed based on self-efficacy. Business success and growth is dependent on the owners' efficacy in all stages from production to marketing.

Economic returns and going concern is dependent on entrepreneurship of a company. According to George (2005), this happens because in entrepreneurship creativity and risk assuming is encouraged throughout organizational processes. This may in turn strengthen the company's presence in existing markets and build competitive edge for the organization.

Researchers and business people value entrepreneurship due to the role it plays towards accelerating organizational performance and reposition in market. The popularity of entrepreneurship is increasing due to the additional value it impacts on the dynamism and repositioning of the corporate organizations in their operating environment. Aspects of entrepreneurship which include innovativeness, dynamism, timeliness and aggressiveness contribute to competitive edge and improved performance of an organization. According to Baldwin \&Gellatly (2003), the current market is seeking for quicker product development, enriched small products and advanced quality all at a lower price. It also calls for entrepreneurial companies to be flexible with the correct environment and structures that will encourage entrepreneurship in its workforces.

\subsection{Statement of the Problem}

This study was necessitated by several considerations. Contracted construction industry is rapidly growing and has therefore attracted very many players. In Kirinyaga County, there are over 500 civil contractors which results in very stiff competition amogst them and subsequently their financial performance is affected. Since the inception of the devolved government, the annual budget implementation report has given evidence that most of the counties have not managed to implement their annual development budget. Implementation is pegged on the small and medium entreprises prequalified to undertake various categories of contractual work(GoK, 2015). This begs the quest for the financial performance of civil contractors in Kirinyaga County, Kenya.

According to the annual budget implementation report for Kirinyaga County the absorption of development budget in the FY 2014/2015 stood at 57.6\% because contractors performance was not evaluted nor monitored. This provoked the need to establish conditions leading to the low absorption rate since entrepreneurship fundamentals were some of the conditions observed. The gap was in getting to know the extents to which the fundametals had affected the absorption rate. The research study wanted to establish whether the financial presentation of the civil contractors had been hampered by individual entrepreneurship factors (RoK, 2015). 
In other instances, the field of entrepreneurship has piqued the interest of other business owners and policy developers. Currently there is little knowledge on how entrepreneurial activities shape financial performance of an organization even though the literature on corporate entrepreneurship shows that its activities have an effect on company's growth (Zahraetal.,2009). Despite numerous kinds of studies on business entrepreneurship, scope of entrepreneurship in developing countries is still recent and lacking (AktanandBulut,2008; Entebang et al., 2006). Therefore, the study planned to add to the literature of entrepreneurship finance by looking at the effect of individual fundamentals of entrepreneurship on the financial performance of contractors in Kirinyaga County, Kenya.

\subsection{Objective of the study}

To determine the effect of individual entrepreneurship essentials on financial performance of civil contactors in Kirinyaga County, Kenya.

\section{Theoretical Framework}

\subsection{Kirzner's Theory of Entrepreneurship}

Kirzner's theory of entrepreneurship was propounded by Kirznerin1997.The theory views entrepreneurship as the conversion of unplanned learning to knowledge, driven by the projection of profit. Spontaneous learning and alertness are held to be the two major fundamentals of entrepreneurship since identifying opportunity is a bigger aspect of entrepreneurship than originality. This is because the task of an entrepreneur is not always about new products but could also be modifying existing products (Harry, 2009).

According to the entrepreneurship model, an entrepreneurships success comes from discovering a gap in the society and acting on it to earn money. Since the opportunity will require resources, the entrepreneur sources for funds by borrowing and later after making sales, repays the loan with the interest accrued (AktanandBulut,2008).

While studying entrepreneurship in a Neo-Austrian dimension, Kirzner sought to answer the question of the contribution of the total process of the economy towards market equilibrium. He found out that it was the competition amongst the entrepreneurs that lead to equilibrium. The competition stemmed from difference in knowledge and information possessed by agents in the market who use it as incentives to the entrepreneurs (de Jong, 2010).

According to this analysis, there is disequilibrium in the economy that can be righted through the production and exchange of opportunities by entrepreneurs who are keen in the environment. The development of entrepreneurship depends on many participants in the business field and sometimes before the business breaks even, loss may be realized. The risktaking aspect of a business deems profit a tentative venture since it requires skills and talent to be able to succeed as entrepreneur. This situation may therefore counteract Kirzner theory (Fernhaber, McDougall-Covin\& Shepherd, 2009). This theory applies to this study because it focuses on individual elements of entrepreneurship of which risk taking is one of them.

\subsection{Innovation Theory}

Innovation Theory was advanced by Schumpeter (1949). In this theory, a businessman who is innovative, creative and possesses foresight is referred to as an entrepreneur. For entrepreneurship to happen, a new product, new way of resources utilization or service must have penetrated a market (Bula, 2012). Schumpeter sought to describe the development of capitalistic system by focussing on the innovation aspect of an entrepreneur. This was different from the neoclassical approach which was looking at how to sustain market equilibrium.

Innovation theory does not recognize the imitative aspect of an entrepreneur but attests that it is the process of entrepreneurship that takes an economy out of equilibrium. Schumpeter posits that the ultimate purpose of entrepreneurship is asserting economic leadership but did not attest that through accumulation one gets to attain social prestige (AktanandBulut,2008). According to Schumpeter, the role of the entrepreneur may not necessarily be that of new inventions but may include looking at how the inventions are useful in production. This will therefore imply that a businessman is an entrepreneur if he applies new ways of using resources in production to move economic system out of the static equilibrium. Civil contractors are hardly innovators but rather use expertise generated by others to fill the gap that arises in the communities (Weerawardena J, \& Mort G. S, 2006).

In another scenario, other economists have increased the scope of entrepreneurship through imitating original products and services in a more superior manner to suit a particular market more than the original invention. The theory spearheads innovation mostly and fails to shed light on the risk-taking aspect of an entrepreneur. It therefore suits large scale ventures since financial conditions allow growing entrepreneurs to be imitative. In the case of developmental projects being sought by the County Government, innovation is not given a chance since most requisitions are custom made and uniformity is highly recognized. However, an entrepreneur must have foresight especially during tender awarding and must be creative in delivery in order to secure the project (Shaw \& Carter, 2007). This theory applies to this study because it is looking at entrepreneurships fundamentals and every entrepreneur is an innovator.

\subsection{Empirical Review}

Individual fundamentals of entrepreneurship are those traits exhibited by intrapreneurship. Study done by Shane et $\mathrm{al}$, (2003) on motivation of entrepreneurs found out that performance of a firm is determined by characteristics inherent to an 
entrepreneur and they include self-drive, personality traits, creativeness and individual abilities to see a business through. Collins, Lock \&Hanges (2000) in their study conclude that control is important in entrepreneurship and people who have control in what is happening in their businesses achieve more and are able to grow their enterprises.

A study done by de Jong and den Hartog (2010) shows that internal control is an attribute associated with entrepreneurs; who also believe that the end result of their businesses is affected by their actions. When studying entrepreneurship, people with inner control are seen to make better entrepreneurs because their actions generate better results. This therefore infers that internal control can be viewed as motivation to be an entrepreneur

According to a study done by Robinson (2011), entrepreneurship is about taking direct action by finding a new approach to dealing with old problems by thinking innovatively and developing new solutions. These solutions could be new products or services needed in the market that are a direct action and not just a pitch in of the entrepreneur. This serves to show the role the entrepreneur plays in the business (Robinson, 2011).

Findings from a study done by Bird (2005) on individual characteristics of entrepreneur's posts that, competency is an observable behaviour that is tied to performance and other entrepreneurship fundamentals such as personality traits, intentions and motivation. Further, entrepreneurship competencies may have a positive effect on one dimension such as development of a new product, and a negative effect on another dimension such as short-term profitability. However, the predominant evidence indicates positive correlations between firms' performance and entrepreneurship competencies.

\subsection{Summary of Literature Review and Gaps}

\begin{tabular}{|c|c|c|c|c|}
\hline $\begin{array}{c}\text { Author and } \\
\text { Year }\end{array}$ & Title & $\begin{array}{c}\text { Findings and } \\
\text { Recommendations }\end{array}$ & Study Gap & Focus of The Study \\
\hline $\begin{array}{l}\text { Hisrich, R. D., } \\
\text { \& Peters, M. } \\
\text { P. (2002). }\end{array}$ & Entrepreneurship & $\begin{array}{l}\text { Entrepreneurship is } \\
\text { dependent on planning } \\
\text { and risk-taking } \\
\text { processes. }\end{array}$ & $\begin{array}{l}\text { The study looked at } \\
\text { process of } \\
\text { formulating, planning, } \\
\text { and implementing a } \\
\text { new business }\end{array}$ & $\begin{array}{c}\text { This study focussed on } \\
\text { individual fundamental of } \\
\text { entrepreneurship in existing } \\
\text { businesses }\end{array}$ \\
\hline $\begin{array}{l}\text { Naldi, L., } \\
\text { Nordqvist, } \\
\text { M., Sjöberg, } \\
\text { K., \&Wiklund, } \\
\text { J. (2007). }\end{array}$ & $\begin{array}{l}\text { Entrepreneurship } \\
\text { Orientation, } \\
\text { Risk Taking, and } \\
\text { Performance in } \\
\text { Family Firms. } \\
\text { Family business } \\
\text { review }\end{array}$ & $\begin{array}{l}\text { In entrepreneurship } \\
\text { placement in private } \\
\text { companies, risk taking } \\
\text { was found to be } \\
\text { negatively associated } \\
\text { with performance. }\end{array}$ & $\begin{array}{l}\text { This study dealt on } \\
\text { risk taking in family } \\
\text { business alone which } \\
\text { are also affected by } \\
\text { other factors }\end{array}$ & $\begin{array}{l}\text { This study focussed on } \\
\text { individual entrepreneurial } \\
\text { fundamentals of civil } \\
\text { contractor }\end{array}$ \\
\hline $\begin{array}{l}\text { Nieuwoudt, S. } \\
\text { (2016) }\end{array}$ & $\begin{array}{c}\text { Entrepreneurship } \\
\text { Characteristics and } \\
\text { Financial } \\
\text { Performance. }\end{array}$ & $\begin{array}{l}\text { The results show that } \\
\text { each of the individual } \\
\text { entrepreneurship } \\
\text { competencies have a } \\
\text { positive } \\
\text { relationship with } \\
\text { the operating efficiency } \\
\text { of the farm. }\end{array}$ & $\begin{array}{l}\text { This study generalized } \\
\text { entrepreneurship } \\
\text { characteristic which } \\
\text { therefore lacked in } \\
\text { depth study }\end{array}$ & $\begin{array}{l}\text { The current study focussed on } \\
\text { individual fundamentals }\end{array}$ \\
\hline $\begin{array}{l}\text { Fernhaber, } \\
\text { S.A } \\
\text { McDougall- } \\
\text { Covin, P.P., \& } \\
\text { Shepherd, } \\
\text { D.A. (2009). }\end{array}$ & $\begin{array}{c}\text { International } \\
\text { Entrepreneurship: } \\
\text { Leveraging Internal } \\
\text { and External } \\
\text { Knowledge Sources. }\end{array}$ & $\begin{array}{l}\text { The study shows that } \\
\text { knowledge in one's are } \\
\text { of operation gave the } \\
\text { business edge as } \\
\text { compared to the others }\end{array}$ & $\begin{array}{l}\text { The study was on the } \\
\text { knowledge sources of } \\
\text { entrepreneurship }\end{array}$ & $\begin{array}{l}\text { This study looked at how } \\
\text { individual fundamentals } \\
\text { affected financial performance } \\
\text { of contractor }\end{array}$ \\
\hline $\begin{array}{c}\text { Shane, S., } \\
\text { \&Venkataram } \\
\text { an, S. (2000). }\end{array}$ & $\begin{array}{l}\text { The Promise of } \\
\text { Entrepreneurship } \\
\text { as a Field of } \\
\text { Research. }\end{array}$ & $\begin{array}{l}\text { The study found out } \\
\text { that entrepreneurs are } \\
\text { faced with many } \\
\text { challenges most of } \\
\text { which have not been } \\
\text { explored and } \\
\text { recommended further } \\
\text { studies on them. }\end{array}$ & $\begin{array}{l}\text { The study focused on } \\
\text { the research aspect of } \\
\text { entrepreneurship }\end{array}$ & $\begin{array}{l}\text { This study looked at how the } \\
\text { individual fundamentals affect } \\
\text { the utility aspect of } \\
\text { entrepreneurship }\end{array}$ \\
\hline
\end{tabular}




\subsection{Conceptual Framework}

From literature review, this study has come up with the following conceptual framework model in order to understand issues regarding individual fundamentals of entrepreneurship and financial performance of civil contractors in Kirinyaga County Kenya. The independent variable focusing on the individual fundamentals studied innovation, proactiveness, personal skills and self-efficacy. The dependent variable on financial performance of civil contractors looked at project cost, operational cost and project return.



Financial performance of Civil Contractors

- Project cost

- Operational cost

- Project retum

Personal skills

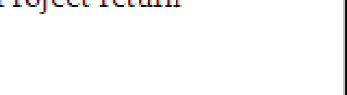

Figure 1: Conceptual Framework

\section{Research Methodology}

\subsection{Study Design}

To achieve the aim of a research, a research design must be identified since it gives guidance on how the study will be undertaken. This study chose the descriptive design because it aims at giving concise and verifiable representation of the data that is related of the study (Kothari, 2008). This design was appropriate in determining the association between, individual fundamentals of entrepreneurship and financial performance of civil contractors in Kirinyaga County, Kenya. The design is appropriate because the study involved an indepth study of entrepreneurs and performance of civil contractors extensively. Descriptive research was also preferred because the researcher had no control over the variable.

\subsection{Target Population}

The target population was 500 civil contractors comprising of 335 fully fledged civil contractors, 90 youth contractors and 60 women who managed companies in both classes of prequalified under the disadvantaged category of suppliers and a further 10 contractors who were registered under the persons with disability category. The respondents under consideration were the active directors of target civil contractors. These were the people who were in the best position to answer questions on issues of entrepreneurship fundamentals that affects the performance of their construction companies indirectly or directly.

\subsection{Sampling Strategy}

The study employed random sampling technique in which $30 \%$ of the population from each stratum was taken to come up with 150 respondents. The purpose of using the study population was to enable the researcher obtain reliable and accurate information from all the levels of respondents and to avoid bias.

\begin{tabular}{|c|c|c|}
\hline Category & Population & Sample (30\%) \\
\hline Main contractors & 335 & 100 \\
\hline Women contractors & 60 & 18 \\
\hline Youth contractors & 90 & 27 \\
\hline $\begin{array}{c}\text { Physically challenged } \\
\text { contractors }\end{array}$ & 15 & 5 \\
\hline Total & 500 & 150 \\
\hline
\end{tabular}

Table 2: Sample Frame of the Study

Source: (Author, 2017)

Conferring with Mugenda and Mugenda (2005), a sample extent of $30 \%$ of the population is appropriate enough to represent the total population in a survey study. 


\subsection{Data Collection Instruments}

The instrument used in the study was a structured questionnaire. Data was gathered mainly using the questionnaire method which had open ended and closed ended questions. The method of collecting data chosen was due to the ease of administering and analyzing the data collected from the field (Gillham, B., 2008). The questionnaires were administered using the drop and collect method.

\subsection{Data Collection Procedure}

Before using the questionnaire for generating data for the study a random pilot study was conducted in twelve construction companies located in Kerugoya Town. The use of pre-testing the research tool was to verify whether the questionnaire was clear to the respondents and establish whether the questionnaire effectively provided data needed for the study. It also assessed and identified any problems respondents would encounter in completing the questionnaire that may not have been foreseen when constructing the questionnaire. The researcher administered the questionnaires and collected them after they were filled on the same day using face to face questionnaires. Suitability of the study was also gauged through the given responses. According to Orodho (2008) piloting is a necessary process as it ensures that measurements are of acceptable validity and reliability.

\subsection{Research Instruments Validity and Reliability}

\subsubsection{Validity}

According toGolafshani (2003) a test of research instrument is said to be valid if it assesses adequately what it was set to measure. The types of construct validity employed in the study were content and discriminant validities. The researcher associated a set of other propositions with the results received from using the questionnaire. Items in the questionnaire were first discussed so as to prove the content validity of the study. In the study, content validity index of 0.802 was computed. For a study to be acceptable, Liptak (2005) endorses a validity index of above 0.5 .

\subsubsection{Reliability}

According toGolafshani (2003) a reliability test of research instruments is one that consistently produces the expected results. Instrument reliability refers to the level of internal consistency or the stability of the measuring devices. Cronbach's alpha reliability index was used in the research study because it averaged correlation of items in the study instrument to measure reliability. The threshold for the study was 0.7 .

Proceeding to the field, the researcher wrote a letter to Kenyatta University to appeal to them for permission to carry out the study. The researcher wrote to NACOSTI to inform them of the aim of carrying out the study. The researcher also sought for authority to collect data from the contractors form County Director Supply Chain in Kirinyaga.

\subsection{Data Analysis Results}

Preparation entailed checking the questionnaire for completeness and legibility. The questionnaire was coded and keyed in using Statistical Package for Social Sciences (SPSS) to facilitate statistical inquiry. Content analysis was also done for the demographic data obtained. This ensured that the data collected was presented in a logical way that provided adequate basis for the generation of conclusions in regard to the specific issue under investigation (Kuada, 2012).

\subsection{Empirical Models}

The civil contractors' performance is measured by project cost, operational cost, client satisfaction, project returns, productivity and contract price and the area of study was the individual entrepreneurship elements. The study analysed quantitative data based on Pearson correlation analysis regression model. The regression model took the form of $\mathrm{Y}=\mathrm{BO}+\beta_{1} \mathrm{X}_{1}+\beta_{2} \mathrm{X}_{2}+\beta_{3} \mathrm{X}_{3}+\beta_{4} \mathrm{X}_{4}+\mathrm{e}$

Where $Y=$ civil contractors performance

$\beta O=$ constant (profit)

$\mathrm{X} 1$ = individual elements of entrepreneurship

$\mathrm{B}_{1}$ is a regression coefficient or change achieved by each $\mathrm{X}$ value.

$\mathrm{e}=$ error term

Pearson's correlation coefficient is used to gauge the strength of a linear connection between two or more data groups. In an example, it is represented by $r$ and is by design controlled as:

$-1 \leq r \leq 1$ where $r$ is the strength of the correlation. Positive relationship is given by positive values and vice versus. 0 signifies no linear association and the closer the value is to 1 or -1 , the stronger the linear correlation (Cohen, Cohen, West \& Aiken, 2003)

According to Sykes (1993), this helped the researcher to assess the statistical implication of the estimated relationships between the variables. Tables and charts were used for visual representation of the key findings. 


\subsection{Ethical Considerations}

In the process of conducting the study, there were various ethical considerations that were factored by the researcher. These were the specific elements that would have undermined the reliability and credibility of the research. One of the main factors was the originality of the data collected. In terms of secondary research, the researcher ensured that the findings and conclusions of different authors were correctly cited and referenced accordingly using APA referencing system. The researcher also sought consent of the respondents before administering the questionnaire and assuring them of confidentiality.

\section{Data Analysis, Presentation and Discussion}

\subsection{Response Rate}

A total of 170 questionnaires were distributed to respondents. In agreement with Mugenda and Mugenda (1999) a $50 \%$ response rate is acceptable, $60 \%$ good while above $70 \%$ is rated very well. The response rate was $88.2 \%$.

\subsection{Bio Data}

The researcher was necessitated to research on the demographic evidence of the respondents so as to achieve the main purpose of the study. This included gender, time engaged in contractor's work sector, age and the level of education

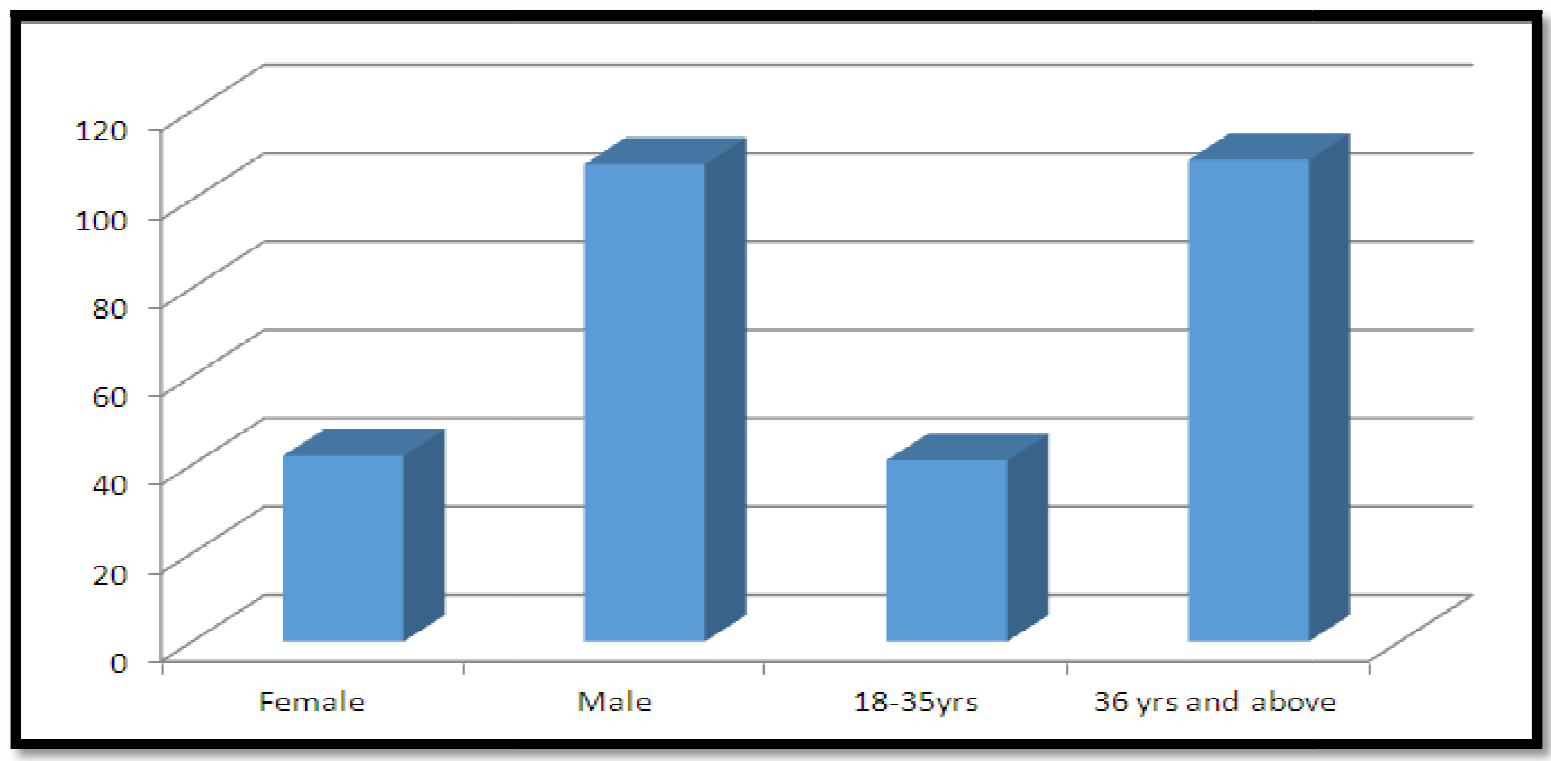

Figure 2: Bio data of the Respondents Source: (Author, 2018)

Age was one of the major determinants in the study so as to be able to know the age group of the respondents and also know whether it had any effect on financial perforrmance of civil contractors in Kirinyaga County. Results obtained from the respondents are presented in Table 4.1 above. Most of the respondents (73\%) were above 35 years while $27 \%$ of the respondents were below 35 years.

The table below sought to find out for how long the entrepreneurs had been civil contractors and what educational or professional qualifications they possessed and which were important in carrying out their jobs.

\begin{tabular}{|c|c|c|}
\hline Demographic Information & Frequency & Percent \\
\hline Time engaged in contractor's work & & \\
0-3 years & 70 & $47 \%$ \\
3-6 years & 33 & $22 \%$ \\
6-9 years & 47 & $31 \%$ \\
Total & 150 & $100.0 \%$ \\
\hline Highest professional qualification & & $7 \%$ \\
Certificate & 10 & $28 \%$ \\
Diploma & 42 & $65 \%$ \\
Degree & 98 & $100 \%$ \\
Total & 150 & \\
\hline
\end{tabular}

Table 3: Demographic Data of the Respondents Source: (Author, 2018) 
From table 3 above, all of the contractors under study had been working on a project by the time the study was carried out. Over $53 \%$ of them had been in the industry for more than 3 years. Over $65 \%$ of the respondents were holders of degree in various fields.

\subsection{Descriptive Analysis}

In the table below, the researcher wanted to find out if the entrepreneurs were subjected to risk taking while undertaking projects.

\begin{tabular}{|c|c|c|}
\hline & Frequency & Percent \\
\hline Strongly disagree & 9 & $6 \%$ \\
\hline Disagree & 6 & $4 \%$ \\
\hline Neutral & 22 & $15 \%$ \\
\hline Agree & 28 & $19 \%$ \\
\hline Strongly agree & 85 & $57 \%$ \\
\hline Total & 150 & $100 \%$ \\
\hline
\end{tabular}

Table 4: Take Financial Risks in Acquiring and Working on Civil Contracts Source: (Author, 2018)

From table 4 above, more than half the respondents agreed that financial risks have to be taken in acquiring and working on civil contracts. This then solidifies the fact that a good entrepreneur must be a risk taker. This is also in line with the literature review where Flyvbjerg, Holm and Buhl (2002) found that in financial management, risk taking encompasses all aspects and decisions, financial and economic, which have an effect on the civil construction projects.

The researcher sought to find out if civil contractors had their work ready for them or they had to seek for opportunities.

\begin{tabular}{|c|c|c|}
\hline & Frequency & Percent \\
\hline Strongly disagree & 5 & $3.4 \%$ \\
\hline Disagree & 4 & $2.6 \%$ \\
\hline Neutral & 12 & $8 \%$ \\
\hline Agree & 18 & $12 \%$ \\
\hline Strongly agree & 111 & $74 \%$ \\
\hline Total & 150 & $100 \%$ \\
\hline
\end{tabular}

Table 5: Go Out of My Way to Seek Out Contracts and Work on Them Source: (Author, 2018)

In table 5 above, the question sought to find out about the proactiveness of the contractor. $86 \%$ of the respondents felt that they always had to source for work rather than wait to be awarded jobs.

\begin{tabular}{|c|c|c|}
\hline & Frequency & Percent \\
\hline Strongly disagree & 5 & $3.4 \%$ \\
\hline Disagree & 5 & $3.4 \%$ \\
\hline Neutral & 12 & $8 \%$ \\
\hline Agree & 28 & $18.6 \%$ \\
\hline Strongly agree & 100 & $66.6 \%$ \\
\hline Total & 150 & $100 \%$ \\
\hline
\end{tabular}

Table 6: Come up with New Ways of Doing the Project Source: (Author, 2018)

Table 6 above shows results of whether innovativeness is part of the process of entrepreneurship. Over 120 of the respondents felt that they had to go out of their way and come up with new ways of handling the projects and being innovative in their products and only $5 \%$ of the respondents disagreed with the variables.

Since the study focussed on the financial performance of civil contractors, the researcher wanted to find out between project cost and operational cost, which carried more weight. 


\begin{tabular}{|c|c|c|}
\hline & Frequency & Percent \\
\hline Strongly disagree & 22 & $6 \%$ \\
\hline Disagree & 16 & $10.6 \%$ \\
\hline Neutral & 8 & $5.3 \%$ \\
\hline Agree & 58 & $38.6 \%$ \\
\hline Strongly agree & 46 & $30.6 \%$ \\
\hline Total & 150 & $100 \%$ \\
\hline
\end{tabular}

Table 7: Financial Risks Incurred Are on Project Cost Rather Than Operational Cost

Source: (Author, 2018)

From table 7 above, while studying financial areas that attracted more risk, the analysis indicates that 104 (69.2\%) of the contractors agreed that financial risks incurred are on project cost rather than operational cost.

\begin{tabular}{|c|c|c|}
\hline & Frequency & Percent \\
\hline Yes & 127 & $85 \%$ \\
\hline No & 23 & $15 \%$ \\
\hline Total & 150 & $100 \%$ \\
\hline \multicolumn{2}{|c|}{$\begin{array}{c}\text { Table 8: Do You Always Finish the Given Project Alone? } \\
\text { Source: (Author, 2018) }\end{array}$}
\end{tabular}

Based on the findings in table 8 above, 127(85\%) of the respondents showed that they finish the given projects alone without assistance from other contractors.

Lastly, the researcher wanted to find if the civil contractor considered project returns as a success factor.

\begin{tabular}{|c|c|c|}
\hline & Frequency & Percent \\
\hline Yes & 142 & $95 \%$ \\
\hline No & 8 & $5 \%$ \\
\hline Total & 150 & $100 \%$ \\
\hline
\end{tabular}

Table 9: Success of the Contract Depends On the Project Returns

Source: (Author, 2018)

According to the findings in table 9 above, majorities of the respondents (over 85\%) indicated that the success of the project depended on the project returns while only $5 \%$ of the respondents indicated that the success of the project did not depended on the project returns but by other factors. These finding collate with the literature review where a study carried by Subramani, Sruthi, and Kavitha (2014) who found that there were non-performance of sub-contractors and increase in material/machine prices and that the competence of the contractor was significantly the cause of poor performance in the projects.

\subsection{Inferential Analysis}

Inferential analysis aims at making inferences on the population of the study based on information gotten from the pilot study. The inferential analysis of the study is based on the regression analysis.

\subsubsection{Model Summary}

\begin{tabular}{|c|c|c|c|c|}
\hline Model & $\mathbf{R}$ & $\begin{array}{c}\text { R } \\
\text { Square }\end{array}$ & $\begin{array}{c}\text { Adjusted R } \\
\text { Square }\end{array}$ & $\begin{array}{c}\text { Std. Error of } \\
\text { the Estimate }\end{array}$ \\
\hline 1 & $.827^{\mathrm{a}}$ & .784 & .852 & .64942 \\
\hline
\end{tabular}

Table 10: Model Summary

Source: (Author, 2018)

As shown in the table 10 above, the $\mathrm{R}$ value $(0.827)$ confirms that the general model is significant. $85.2 \%$ of financial performance of civil contractors as represented by the adjusted $\mathrm{R}^{2}$ shows that studying individual fundamentals was right for the research. This therefore means that performance of civil contractors can be explained by only $14.8 \%$ other of factors not studied in this research. These results are in agreement with Fudge and Wolfe (2008) who argues that factors influencing performance of civil contractors are individual, organizational, environmental and social based fundamental factors. 


\subsubsection{ANOVA}

\begin{tabular}{|c|c|c|c|c|c|c|}
\hline \multicolumn{9}{|c|}{ ANOVA $^{\mathbf{a}}$} \\
\hline \multicolumn{2}{|c|}{ Model } & Sum of Squares & df & Mean Square & F & Sig. \\
\hline \multirow{2}{*}{1} & Regression & 10.939 & 5 & 2.188 & 5.188 & $.002^{\mathrm{b}}$ \\
\cline { 2 - 7 } & Residual & 5.061 & 12 & .422 & & \\
\cline { 2 - 7 } & Total & 16.000 & 17 & & & \\
\hline & & & & & \\
\hline
\end{tabular}

Table 11: ANOVA

Source: (Author, 2018)

From table 11 above, the significance value of the study was 0.002 which was less than 0.05 . This concludes that the model is statistically significant in forecasting how individual, organizational, environmental and social based fundamental factors influence performance of civil contractors. The F critical at $5 \%$ level of significance was 2.52 and lower than F calculated (5.188) showing that the overall model was significant.

\subsubsection{Coefficients}

\begin{tabular}{|c|c|c|c|c|c|}
\hline Model & $\begin{array}{c}\text { Unstandardized } \\
\text { Coefficient }\end{array}$ & & $\begin{array}{c}\text { Standardized } \\
\text { Coefficient }\end{array}$ & T & Sig, \\
\hline & $\mathrm{B}$ & Std. Error & Beta & & \\
\hline Constant & .505 & .441 & & 1.115 & .256 \\
\hline $\begin{array}{c}\text { Individual } \\
\text { fundamentals }\end{array}$ & .390 & .093 & .292 & 3.115 & .003 \\
\hline
\end{tabular}

Table 12: Coefficients

Source: (Author, 2018)

According to the findings, the recognized regression equation was;

$$
\mathrm{Y}=0.505+0.292 \mathrm{X}_{1}
$$

The regression equation depicted above shows that putting all factors into considerations, the performance of civil contractors affected by individual fundamentals was 0.505 with a beta coefficient of 0.292 . The findings were positive and hence the model was suitable for the study. According (Cohen et al., 2003) positive relationship is given by positive values and vice versus. 0 signifies no linear association and the closer the value is to 1 or -1 , the stronger the linear correlation.

\section{Summary of Findings}

The study sought to examine the effect of entrepreneurship fundamentals on financial performance of civil contactors in Kirinyaga County, Kenya. The study found out that individual entrepreneurship fundamentals had a statistically significant effect on fiscal performance of civil contractors in Kirinyaga County with risktaking being a strong factor in the many qualities that an entrepreneur is supposed to have.The findings presented showed that individual entrepreneurship fundamentals had an important positive effect on financial performance of civil contactors as shown by a coefficient of 0.292 and a p-value of 0.003 at 5 $\%$ significance level which is less than 0.05 and a $t$-value of 3.115 which is greater than 2 . This infers that there is a positive significant relationship between individual fundamentals performance of civil contractors and that entrepreneurs with stronger qualities in risk taking, innovation, self efficacy and competence perform better than their counterparts financially.

\section{Conclusion}

The study concluded that individual entrepreneurship fundamentals had a statistically significant effect on fiscal performance of civil contractors in Kirinyaga County with innovations and self efficacy being a strong factor.

\section{Recommendations}

From the findings on the effect of entrepreneurship fundamentals, the study recommends that the county governments should develop training modules on how to handle financial risks, increase technical competence and learn about governance for existing and upcoming civil contractors. The study also commends that further studies on other fundamentals that affect entrepreneurship be carried out.

\section{References}

i. Aktan,B., \& Bulut, C. (2008). Financial Performance Impacts of Corporate Entrepreneurship in Emerging Markets: A Case of Turkey. European Journal of Economics, Finance and Administrative Sciences,12(8), 1530-2275. 
ii. Baldwin, J. R., \&Gellatly, G. (2003).Innovation Strategies and Performance in Small Firms.Edward Elgar Publishing.

iii. Bird, B., \&Schjoedt, L. (2009). Entrepreneurial behavior: Its nature, scope, recent research, and agenda for future research. In Understanding the entrepreneurial mind (pp. 327-358). Springer, New York, NY.

iv. Boyatzis, R., McKee, A., \&Goleman, D. (2002).Reawakening Your Passion for Work. Harvard Business School Publishing Corporation.

v. Cohen, J., Cohen P., West, S. \& Aiken L, (2003). Applied Multiple Regression/Correlation Analysis for the Behavioural SciencesNew York: John Wiley \& Sons.

vi. Collins, C., Locke, E., \&Hanges, P. (2000). The relationship of need for achievement toentrepreneurial behaviour: a meta-analysis. Working paper, University of Maryland,College Park, MD.

vii. De Jong, J., \& Den Hartog, D. (2010).Measuring Innovative Work Behaviour.Creativity and Innovation Management, 19(1), 23-36.

viii. Fudge, N., Wolfe, C. D., \&McKevitt, C. (2008). Assessing the promise of user involvement in health service development: ethnographic study. Bmj, 336(7639), 313-317.

ix. George, A. L., \& Bennett, A. (2005).Case Studies and Theory Development in the Social Sciences.MIT Press.

x. Golafshani, N. (2003). Understanding Reliability and Validity in QualitativeResearch.The Qualitative Report,8(4), 597606.

xi. Gillham, B. (2008). Developing a Questionnaire (2nd ed.). London, UK: Continuum International Publishing Group Ltd

xii. Mugenda O.M. and Mugenda G.A., (2005).Research Methods: Qualitative and Quantitative Approaches. Nairobi: Acts Press

xiii. Huse, M. (2005).Accountability and Creating Accountability: A Framework for Exploring Behavioural Perspectives of Corporate Governance.British Journal of Management, 16(s1), S65-S79.

xiv. Ireland, R. D., Hitt, M. A., \&Sirmon, D. G. (2003).A Model of Strategic Entrepreneurship: The Construct and its Dimensions.Journal of management, 29(6), 963-989.

xv. Orodho AJ (2008). Essentials of Educational and Social Science Research Methods.Nairobi: Mazola Publishers

xvi. Robinson, S., \&Stubberud, H. A. (2011).Social networks and entrepreneurial growth.International Journal of Management and Information Systems, 15(4), 65.

xvii. Shane, S., Locke, E. A., \& Collins, C. J. (2003).Entrepreneurial motivation.Human resource management review, 13(2), 257-279

xviii. Shane, S., \&Venkataraman, S. (2000).The Promise of Entrepreneurship as a Field of Research.Academy Of Management Review,25(1), 217-226.

xix. Shaw, E., \& Carter, S. (2007). Social Entrepreneurship: Theoretical Antecedents and Empirical Analysis of Entrepreneurship Processes and Outcomes.Journal of Small Business and Enterprise Development, 14(3), 418-434.

xx. Subramani, T., Sruthi, P. S., \&Kavitha, M. (2014). Causes of cost overrun in construction. IOSR Journal of Engineering, 4(6), 1-7.

xxi. Weerawardena, J., \& Mort, G. S. (2006).Investigating Social Entrepreneurship: A Multidimensional Model.Journal of world business, 41(1), 21

xxii. Zahra, S. A., Gedajlovic, E., Neubaum, D. O., \& Shulman, J. M. (2009).A Typology of Social Entrepreneurs: Motives, Search Processes and Ethic Challenges. Journal of business venturing, 24(5), 519-532

xxiii. Zakaria, Z., Hussin, Z. H., Noordin, N. (2010). Accidents at the Construction site in Northern Area: Malaysian Experienced. Management Science and Engineering, 4(3), 106-116.

Sample Questionnaire

\section{Appendix}

\section{PART A: General Information}

Tick the appropriate box

1. Gender

Male

Female

2. Age

18-35 years

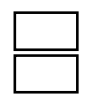

3. Period of time engaged in contractors work

$0-3$ years

$3-6$ years

$6-9$ years

Over 9 years

36 years and above

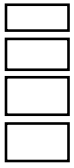


4. Your highest professional qualification
a) Certificate
b) Diploma
c) Degree
d) Post graduate
e) Any other



5. In which category are you classified in the County prequalified list of contractors?

Main Category

Women

Youth

Physically challenged

A. Individual Entrepreneurship Fundamentals

A. Which unique personal skills do you possess that give you advantage in your contactors work......Provide a choice

B. Use the five point scale to answer the question where

1. Strongly disagree, 2. Disagree, 3 . Agree, 4 . Strongly agree, 5 . Very strongly agree

a I take many financial risks in acquiring and working on civil contracts

b. I must always go out of my way to seek out contracts and work on them
1
2
3
4
5

c. Every time there is a new project, I must come up with new ways of doing the project
1
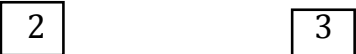
4
5

d. Do you always finish the given project alone

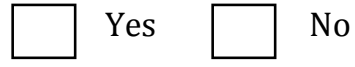

eI face bigger risks when dealing with project costs than when dealing with operational costs

\begin{tabular}{|l|l|l|}
\hline 2 & 3 & 4 \\
\hline
\end{tabular}

f. Success of the contract depends on the project returns rather than the many projects undertaken

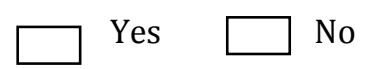

B. Financial Performance of Civil Contractors

Use the Five Point Scale to Answer the Question Where

1. Very high extent, 2. High extent, 3.Always, 4.Moderate Extent, 5 No effect

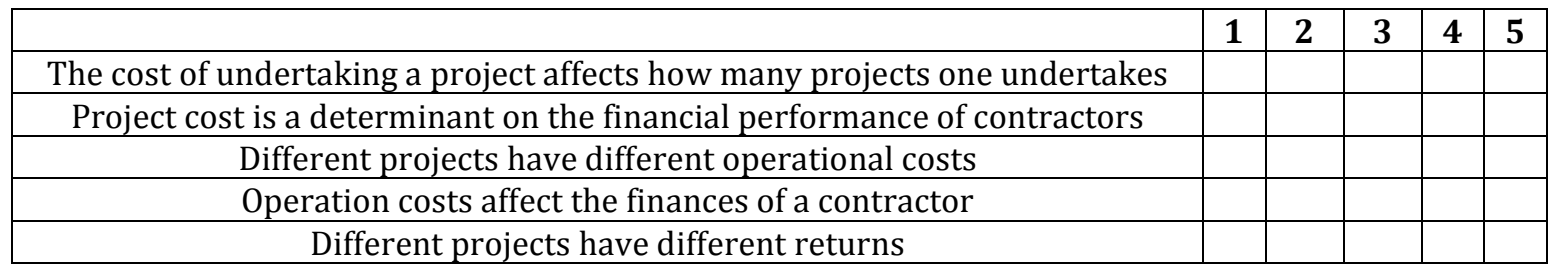

Thank you 
